\title{
Prevalence and Consequences of Misuse of Antibiotics, Survey Based Study in Karachi
}

Naveed S*, Qamar F, Maqsood A, Ayub A, Kauser H, Malik H, Fatima K and Hameed A

Jinnah University for Women, Karachi, Pakistan

\begin{abstract}
Antibiotic misuse is one of the major problems of our society. This is the survey based study that was designed to check the prevalence of antibiotic misuse and to prevent the emergence of antibiotics resistance. Different questions were asked to 200 university students in the month of November-2014. According to our survey report, $52.5 \%$ participants got infections yearly, $70 \%$ use antibiotics rarely, $68.5 \%$ purchase antibiotics outside of hospitals, $77 \%$ purchase antibiotic only on prescriptions, only $47.5 \%$ seek advice from health care professionals, $83 \%$ follow complete course, $65 \%$ thinks antibiotics are not effective anymore, $73.5 \%$ didn't experienced any side effects from antibiotics, $41 \%$ don't know that the misuse of antibiotic is harmful, while only $27.5 \%$ thinks that the antibiotics used will be effective in future for the same infection. We concluded that the major factor that leads to antibiotic misuse and its resistance is lack of awareness.
\end{abstract}

\section{Keywords: Antibiotics; Misuse; Resistance; Prescription}

\section{Introduction}

Although the antibiotics have wide variety of uses but still there misuse can lead to resistance towards wide range of pathogens and bacteria. This may lead to face new set of threats to public health [1]. The pattern of resistance towards microbial agents is different for developed and developing countries. In developing countries there are resistant microorganisms which are still regarded as susceptible in developed countries. So the criteria for treating pathogens with antimicrobial agents are different at the level of developed and developing countries [2]. Antibiotics resistance with some microorganisms is becoming a serious problem especially for our community. This resistance is developing just because of misuse of antibiotics. The reason behind inappropriate use of antibiotics may be that people use antibiotics on self-medication basis and don't follow complete pattern regarding the use of antibiotics. Once resistance has been established it can't be reversible and hence it will be difficult to treat variety of different infections caused by different organisms [3].

There may be several factors leading to the misuse or overuse of antibiotics. These factors which lead to misuse of antibiotics may be at the patient level or at the level of doctors. Behind misuse of antibiotics several factors are laying that resist patient to use antibiotics appropriately. These factors can me named as cultural factors, behavioral factors, socio-economic status of patients and level of education both at the level of health care professionals and patients especially in our community Karachi [4]. It may be concluded that in developing countries the antibiotics that are at the level of bacterial resistance are generally inexpensive and broad spectrum. It is not wrong to say that the misuse of antibiotics is more at clinical practices rather than at public health personnel, because it is more common at the level of private practitioners that they charge higher fees and here the demands for antibiotics is higher and hence because of this reason more drugs are available in private clinics as compared to public hospitals. It is also common in most of the developing countries that the purchasing of antibiotic is done without prescription. This practice is more common in African, Asian and Latin American countries. Antibiotics can be available readily at patent drug stores, roadsides and hawkers, and hence in turn people don't use antibiotics for particular exact type of infections and if it is for particular type of infection than they don't follow complete course of that antibiotic which leads to resistance [5].
To treat several infections caused by pathogens including methicillin resistant staphylococcus aureus, penicillin resistant streptococcus pneumonia and vancomycin resistant enterococci is now a great issue. New solutions should be encouraged to treat all these infections. These solutions may include that proper vaccination should be followed, while taking antibiotics its improved use should be considered. Clinicians must pay keen interest to promote improved use of antibiotics by their community [6].

In recent years it is considering that antibiotics era might be coming to an end because of increased resistance of pathogens towards antibiotics and because of decreased production of new agents [7]. Most of the people think that antibiotics are effective for common cold. Mostly people of developing countries think that even for minor common cold and flu like symptoms antibiotics are best choice and use on the basis of self-medications. Another study has shown that most of the people don't follow complete course of antibiotics because they feel better [8]. One of the major risk factor of now a day is that the clinically important bacteria are not characterized by single resistant antibiotic only but by multi resistant antibiotics too [9]. Misuse of antibiotics most commonly occur in case of diarrheal illness and respiratory diseases by health professional, lay person and unskilled practitioners. This aspect is more common in developing countries [10].

Many different species especially of nosocomial pathogens and also of community acquired organisms resist the inhibitory action of microbial agents. Control of this resistance pattern depends on how resistance pattern has been observed but this criterion is much more difficult as it is varied from organism to organism [11]. The only way that is left is just to encourage individuals to follow rational use of drugs. Other parameter that may strengthen this is just to raise

*Corresponding author: Safila Naveed, Jinnah University for Women, Karachi Pakistan, Tel: 00923002621917; E-mail: safila117@yahoo.com

Received May 26, 2015; Accepted June 08, 2015; Published June 16, 2015

Citation: Naveed S, Qamar F, Maqsood A, Ayub A, Kauser H, et al. (2015) Prevalence and Consequences of Misuse of Antibiotics, Survey Based Study in Karachi. J Bioequiv Availab 7: 202-204. doi:10.4172/jbb.1000240

Copyright: $\odot 2015$ Naveed S, et al. This is an open-access article distributed under the terms of the Creative Commons Attribution License, which permits unrestricted use, distribution, and reproduction in any medium, provided the original author and source are credited. 
awareness among patients and society by conducting different seminars emphasizing on how to avoid misuse of antibiotics [12]. The question arises in mind that how basically the resistance develops? Because of inaccurate and misuse of antibiotics gene expressing resistance to these antibiotics have been emerged in strains of bacteria that cause hindrance in the treatment of infection and has spread in global ecosystem that cause infection to progress [13]. The mechanism of actions behind resistance to bacteria is due to impermeability of the drug and gene mutation. Just because of these reasons now the minute infections become very difficult to treat and hence lead to serious health problems in our country [14]. As we have done such types of work earlier [15-22].

\section{Methodology}

This is the study which was based on survey on misuse of antibiotics. A cross-sectional and random sampling method was used to collected data. The study was carried out in Karachi, in the month of November 2014. A questionnaire was designed consisting of 10 questions for the collection of data. Data was collected from $200(n=200)$ university students belonging to different universities of Karachi, Pakistan. Questions were asked to different individuals and the questions included were mostly of close ended type questions. They had just to choose the answers from the given options.

\section{Data analysis}

We have statistically analyzed our results to evaluate the antibiotic misuse in our city and used spss 16.0.

\section{Result}

In this survey we have sampled 200 people. About 105 (52.5\%) of participants told that they got yearly infections, while 41 (20.5\%) and 54 (27.5\%) of participants got monthly and weekly infections respectively. In this regard we concluded that the prevalence of infection is not at a rapid rate. About $70.0 \%$ (140) of participants told that they use antibiotics rarely. $19.5 \%$ (39) of the participants told that they use antibiotics mostly. The prevalence of use of antibiotics in the participants is shown in the Table 1. About 137 (68.5\%) of the participants use to purchase antibiotics outside of the hospital. While 63 (31.6\%) of the participants interpret that they do not purchase antibiotics outside of the hospital. Data regarding the purchase of antibiotics outside of the hospital is shown in Table 1. About $154(77.0 \%)$ of participants purchase antibiotics with prescription while only 46 (23.0\%) of the participants interpret that they do not use antibiotics with prescription. The frequency and percent for this question was tabulated in Table 1. The previous question was followed by the other was that if they don't use antibiotics with prescription than they seek advice from any of the health care professional or not? About 105 (52.5\%) of the participants don't seek any of the advice from health care professional while only $95(47.5 \%)$ seek advice. This data is helpful in the prevalence of resistance pattern. Data is tabulated in Table 1. About $166(83.0 \%)$ of the participants follow complete course of antibiotics while only 34 (17.0\%) of the participants don't follow complete course of antibiotics. Data is shown in Table 1 the participants showed the following pattern in regards of the frequency of effectiveness of antibiotics. About $65.0 \%$ (130) participants told that they don't think the antibiotics they are using were not effective anymore. While 19.5\% (39) and 15.5\% (31) of the participants answer positively or don't know respectively. Data is tabulated in Table 1. The participants were inquired for any experience of minor or serious side effects was also asked. Following frequency pattern was observed in regard to this question. About 147 (73.5\%) of the participants interpret that they didn't experience any of the serious or minor side effects to antibiotics use, while about 53 (26.5\%) of the participants told that they experienced. Details regarding this data are tabulated in Table 1. Misuse of antibiotics can be harmful and one of the main reasons behind the prevalence of resistance patterns in antibiotics is their misuse. About $41.0 \%$ (82) participants don't know the misuse of antibiotics is harmful but in turn about $59.0 \%$ (118) participants have knowledge about the misuse of antibiotics is harmful. Although the percent of participants who don't know is less but still it is a matter of keen concentration that the major percent of individuals don't know that misuse of antibiotics is harmful. This should be minimized by spreading among the individuals of community. Data is shown in Table 1. Following is the frequency pattern in regards of the effective treatment of the same infection in future by the same antibiotic. About 99 (49.5\%) of the participants don't know as if the antibiotic will be effective for the same infection in future. While $55(27.5 \%)$ of the participants told that they think the antibiotic will be effective in future for the same infection. On the other hand 46 (23.0\%) of the participants told that don't know.

\begin{tabular}{|l|l|l|l|l|}
\hline \multicolumn{4}{|l|}{ Question 1:- How often you get infections? } \\
\hline & Frequency & Percent & Valid Percent & $\begin{array}{l}\text { Cumulative } \\
\text { Percent }\end{array}$ \\
\hline Monthly & 41 & 20.5 & 20.5 & 20.5 \\
\hline weekly & 54 & 27 & 27 & 47.5 \\
\hline yearly & 105 & 52.5 & 52.5 & 100 \\
\hline Question 2:- How often do you use antibiotics? & \\
\hline Mostly & 39 & 19.5 & 19.5 & 10.5 \\
\hline Rarely & 140 & 70 & 30 \\
\hline Question 3:- Do you purchase antibiotics outside of the hospital? \\
\hline No & 63 & 31.5 & 31.5 \\
\hline yes & 137 & 68.5 & 100 \\
\hline Question 4:- Do you purchase antibiotics with prescription? \\
\hline NO & 46 & 23 & 23 \\
\hline YES & 154 & 77 & 100 \\
\hline
\end{tabular}

Question 5:- If not than do you seek advice from any of the health care professional or not?

\begin{tabular}{|l|l|l|l|l|}
\hline NO & 105 & 52.5 & 52.5 & 52.5 \\
\hline YES & 95 & 47.5 & 47.5 & 100 \\
\hline
\end{tabular}

Question 6:- Do you follow complete course of antibiotics or not?

\begin{tabular}{|l|l|l|l|l|}
\hline NO & 34 & 17 & 17 & 17 \\
\hline YES & 166 & 83 & 83 & 100 \\
\hline Total & 200 & 100 & 100 & \\
\hline
\end{tabular}

\begin{tabular}{l|l|l|l} 
Total 200 & 100 & 100 \\
\hline Question 7:- Do you think the antibiotics you are using were not effective
\end{tabular} Question 7:-

\begin{tabular}{|l|l|l|l|l|}
\hline NO & 130 & 65 & 65 & 65 \\
\hline YES & 39 & 19.5 & 19.5 & 84.5 \\
\hline don't know & 31 & 15.5 & 15.5 & 100 \\
\hline
\end{tabular}

Question 8:- Have you experienced any of the minor or serious adverse effects to antibiotics?

\begin{tabular}{|c|c|c|c|c|}
\hline NO & 147 & 73.5 & 73.5 & 73.5 \\
\hline YES & 53 & 26.5 & 26.5 & 100 \\
\hline \multicolumn{5}{|c|}{ Question 9:- Do you know the misuse of antibiotics can be harmful? } \\
\hline NO & 82 & 41 & 41 & 41 \\
\hline YES & 118 & 59 & 59 & 100 \\
\hline \multicolumn{5}{|c|}{$\begin{array}{l}\text { Question 10:- Will an antibiotic always be effective in the treatment of same } \\
\text { infection in future? }\end{array}$} \\
\hline NO & 99 & 49.5 & 49.5 & 49.5 \\
\hline YES & 55 & 27.5 & 27.5 & 77 \\
\hline don't know & 46 & 23 & 23 & 100 \\
\hline
\end{tabular}

Table 1: Frequency and percentage of all questions. 
Citation: Naveed S, Qamar F, Maqsood A, Ayub A, Kauser H, et al. (2015) Prevalence and Consequences of Misuse of Antibiotics, Survey Based Study in Karachi. J Bioequiv Availab 7: 202-204. doi:10.4172/jbb. 1000240

\section{Discussion}

The basic purpose behind designing this study is to prevent the emergence of antibiotic resistance. This study was based on different questionnaire designed to interpret the misuse of antibiotics among the students. Results showed that there is lack of awareness among the community that the use of antibiotics can develop resistance pattern. And hence at last we will have no choice for the treatment of even minor infection. In this study we have sampled only 200 students, which is the small data but still it's very much important for the evaluation of emergence of resistance. Students included were mostly linked to medical field. And much of them have awareness regarding the misuse of antibiotics. But still a major percent of participants don't have knowledge regarding the misuse of antibiotics.

Basic knowledge regarding the difference in between Over the Counter drugs and antibiotics should be cleared among the individuals. Pharmacist must ensure that antibiotics should be given with prescription not without prescription. One of the major causes behind the prevalence of resistance pattern among antibiotics is that people usually don't seek advice from any of the health care professional if they purchase antibiotics without prescription. As a result it leads to antibiotics misuse. Other factor that may lead to antibiotic resistance is that most of the individuals don't follow complete course of antibiotics for a particular infection. It may be a prescribing error. It is the responsibility of health care professionals that they must counsel patients that for how much period of time they have to use antibiotics. In Pakistan physicians usually don't mention and hence in turn either the use of antibiotics may lead towards its misuse or in most cases patients don't follow complete course of antibiotics just because of the lack of counseling or awareness among our community. This may be a reason behind self-medication of antibiotics that in our community most of the individuals can't afford high costs of hospital care and also the long delays in clinics and hospitals may be the reason behind selfmedication of antibiotics. We think that the only solution to solve the antibiotics resistance is to spread medical awareness and by giving basic medical education among the individuals of different age group.

\section{Conclusion}

Based on the calculated percent and frequency of our result we concluded that a major population of our community is using antibiotics without having awareness regarding its proper use. There is an urgent need of those measures that can be taken to solve the emergence of antibiotics resistance.

\section{References}

1. Carson J (1968) Misuse of Antibiotics. Br Med J 1: 512.

2. Soyka LF, Robinson DS, Lachant N, Monaco J (1975) The misuse of antibiotics for treatment of upper respiratory tract infections in children. Pediatrics 55: 552-556.

3. Wolff MJ (1993) Use and misuse of antibiotics in Latin America. Clin Infect Dis 17 Suppl 2: S346-351.

4. Levy SB (2002) The antibiotic paradox: how the misuse of antibiotics destroys their curative powers, Da Capo Press.

5. Pechere JC (2001) Patients' interviews and misuse of antibiotics. Clin Infect Dis 33 Suppl 3: S170-173.

6. Gibbons RP, Stark RA, Correa RJ Jr, Cummings KB, Mason JT (1978) The prophylactic use--or misuse--of antibiotics in transurethral prostatectomy. J Urol 119: $381-383$

7. Al-Ghamdi S, Gedebou M, Bilal NE (2002) Nosocomial infections and misuse of antibiotics in a provincial community hospital, Saudi Arabia. J Hosp Infect 50: 115-121.

8. Edwards DJ, Richman PB, Bradley K, Eskin B, Mandell M (2002) Parental use and misuse of antibiotics: are there differences in urban vs. suburban settings? Acad Emerg Med 9: 22-26.

9. Carey B, Cryan B (2003) Antibiotic misuse in the community--a contributor to resistance? Ir Med J 96: 43-44, 46

10. Tzialla C, Borghesi A, Perotti GF, Garofoli F, Manzoni P, et al. (2012) Use and misuse of antibiotics in the neonatal intensive care unit. $J$ Matern Fetal Neonatal Med 25: 35-37.

11. Slama TG, Amin A, Brunton SA, File TM Jr, Milkovich G, et al (2005) A clinician's guide to the appropriate and accurate use of antibiotics: the Council for Appropriate and Rational Antibiotic Therapy (CARAT) criteria. Am J Med 118 Suppl 7A: 1S-6S.

12. Kunin CM, Tupasi T, Craig WA (1973) Use of antibiotics. A brief exposition of the problem and some tentative solutions. Ann Intern Med 79: 555-560.

13. English BK, Gaur AH (2010) The use and abuse of antibiotics and the development of antibiotic resistance. Adv Exp Med Biol 659: 73-82.

14. Farid Z, Miner WF, Hassan A, Trabolsi B (1975) Letter: Misuse of antibiotics. N Engl J Med 292: 216.

15. Naveed S, Qamar F, Zainab S, Sarwer G (2014) A Survey Study on awareness of Hepatitis $C$ in different groups. WJPS 2: 449-454.

16. Naveed S, Rehman N, Rehman S, Malick S, Yousuf S, et al. (2014) Knowledge and Attitude about Crimean Congo Hemorrhagic Fever (CCHF) Amongst Local Residents Of Karachi, Pakistan. J App Pharm 6: 166-170.

17. Naveed S, Syed R, Zafar A, Tariq T, Wasif N, et al. (2014) Prevalence Of Ora Submucous Fibrosis And Use of Tobacco And Related Products. Mintage journal of Medical and pharmaceutical Sciences 3: 4-6.

18. Naveed S, Baig AA, Jameel A, Nadeem F, Qazi M, et al. (2014) Increased use of cephalosporin as first line agent instead of penicillin. World J Pharm Sci 2 : 270-275

19. Naveed S, Zafar IN, Musharraf M, Yaqoob S, Zaman S, et al. (2014) Pharmacy Dispensing Practice In Various Pharmacies Of Karachi. Mintage Journal of pharmaceutical and medical sciences 3: 19-21.

20. Kafeel H, Rukh R, Naveed S (2014) Evaluation Of Patient Counseling In Different Hospital Of The Karachi; A Neglected Domain Of Pharmacy. Int Res J Pharm 5: 203-204.

21. Naveed S (2014) Gender Related Differences and Modifying Risk Factors among Stroke Patients. IJETPS 2: 1-4.

22. Naveed S, Ali M (2014) Evaluation/Determination of Lack Dose Calculation in Geriatric Patient in Different Hospital Of Karachi. Asian Journal of Pharmaceutical Technology \& Innovation 2: 01-06. 